\title{
DEVELOPMENT IN THE USE OF COCONUT FARM RESIDUES FOR THE MANUFACTURE OF COIR-WOOD-CEMENT AS ALTERNATIVE CONSTRUCTION MATERIAL
}

\author{
BY \\ R. N. Palomar, L. J. Penamora and N. J. Melencion ${ }^{1}$
}

\begin{abstract}
A new product using farm wastes from coconut plantation is being developed as an alternative building material. The product, coir-wood-cement board (CWCB), is made from husk fiber of coir and shredded sapling or excelsior that are mixed separately with cement at a predetermined ratio of $70 \%$ cement to $15 \%$ coir excelsior by weight basis.

Mixture of saturated coir/excelsior and cement is mat-formed and pressed to the desired thickness and then conditioned by air-drying to produce CWCB. Its dimension is $61 \mathrm{~cm}$ wide and $244 \mathrm{~cm}$ long with thickness ranging from $8 \mathrm{~mm}$ to $25 \mathrm{~mm}$

CWCB meets the strength requirements set by PHILSA standard specification for particleboard (PHILSA 106, 1975). It is being service-tested as an alternative material for expensive construction materials such as plywood, particleboard and cement hollow blocks. It has been found suitable for such uses as exterior/interior walls, partition panel and ceiling of building as well as furniture components such as table top and cabinet siding.

Production of CWCB needs the major equipment/machinery such as decorticating machine, shredding machine, blending machine, hydraulic press, trimmer and lifter. Except for lifter, these machines can be designed and fabricated locally. Estimated total investment cost of PhP 3.76 million is needed to establish a CWCB plant that includes equipment, land rental, building and working capital. About 37,500 boards can be produced every year with internal rate of return of $35.20 \%$ and payback period of 2.68 years.
\end{abstract}

\section{INTRODUCTION}

The prohibitive cost of conventional boards such as plywood and particle board leads to continuing research and development efforts to find affordable new and alternative materials for construction purposes. Coir-wood-cement board (CWCB) is an example of alternative panel that can be produced from farm residues and can be used instead of the traditional expensive construction materials such as plywood, asbestos and cement hollow-blocks.

Coconut husks, as well as fronds, are cellulosic residues considered as wastes. These are abundant in coconut plantations and are usually left in the farm to decompose or disposed by burning for phytosanitary reason. In addition, small diameter trees such as ipil-ipil, bagalunga and other fastgrowing indigenous trees are likewise abundant in coconut plantations, either as intercrop or naturally grown. These trees are normally used merely as firewood or fence post. Most of the time, they are left on the ground to rot after clearing or underbrushing.

Cognizant of this situation, the PCA-Zamboanga Research Center embarked on an R \& D program to explore proper disposal and economic use of these farm residues, the product of which is the $\mathrm{CWCB}$ as a new construction material.

\footnotetext{
1 Division Chief III, Senior Science Research Specialist and Science Research Specialist, respectively, Philippine Coconut Authority, Zamboanga Research Center, San Ramon, Zamboanga City, Philippines.
} 


\section{MANUFACTURING PROCESS OF CWCB}

There are three major components in the manufacture of CWCB, namely: a) coir, b) wood excelsior, and, c) cement. The production of CWCB involves the following steps:

1. Processing of husks

a. Soaking of dried husk in tap water for 18-24 hours. However, green husks that contain high moisture content can be immediately decorticated

b. Decorticating of soaked husks to separately produce coir and dust only coir is used in board production while the dust may be used as soil conditioner.

2. Processing of small diameter trees (maximum diameter of $14 \mathrm{~cm}$ )

a. Cutting of log into $42 \mathrm{~cm}$ long billets

b. Debarking of billets

.c. Shredding the billets to produce excelsior or curled shavings of wood.

3. Soaking the coir and excelsior in separate dipping tanks (each tank has a capacity of $12 \mathrm{cu} . \mathrm{m}$.) full of water for two to three days to leach out extractives.

4. Collecting the coir and excelsior from the dipping tanks and allowing water to drain from the coir and excelsior for about 5 minutes

5. Weighing separately the coir, excelsior and cement with a ratio of $15 \%$ fiber, $15 \%$ excelsior, and, $70 \%$ cement.

6. Mixing separately the required amount of coir and excelsior with cement in a blending machine

7. Mat-forming using wooden forming boxes and flat steel cauls lined with polyethylene sheets. Three layers of mat are formed to produce a CWCB. The first layer is a mixture of excelsior and cement, the second is a mixture of coir and cement, and the last layer is the same mixture as the first layer. Viewed in cross-section, the coir layer is embedded in-between the excelsior layers. The coir serves as reinforcement to improve the strength properties of the board.

8. Pressing the mat to the desired thickness using guide bars, hydraulic press and clamping apparatus. Twenty-five layers of CWCB can be pressed at the same time for approximately 10 minutes and then securely clamped or fastened using wooden moulds, bolts and nuts that serve as clamping apparatus.

9. The fastened/clamped CWCB is removed from the hydraulic press and another set of 25 layers of CWCB is again prepared for pressing following steps $7 \& 8$. About six pressing operations can be attained per day giving a daily output of 150 boards.

10. After 18 to 20 hours under pressure, the boards are removed from the clamping apparatus and properly piled using $25 \mathrm{~cm} \times 25 \mathrm{~cm} \times 60 \mathrm{~cm}$ wooden sticks to provide air circulation (filletstacking) during the initial 24-hour air drying and conditioning.

11. Trimming the edges of the boards to the desired dimension.

12. Fillet-stacking for further drying and conditioning for about one week. 


\section{EQUIPMENT/MACHINERY}

The major equipment/machinery used in the manufacture of CWCB are all fabricated locally, except the lifter, and include the following:

\section{Decorticating Machine}

The machine is composed of a cylinder measuring $80 \mathrm{~cm}$ in diameter and $120 \mathrm{~cm}$ in length and made of flat iron sheet $9.5 \mathrm{~cm}$ in thickness. The cylinder houses the rotary assembly.

The rotary assembly, which decorticates/defiberizes the husk, has a total of 24 blades. The blades, each measuring $2.0 \mathrm{~cm} \times 5.0 \mathrm{~cm} \times 40.0 \mathrm{~cm}$, are made of flat steel bards bolted to flanges which are welded to a steel shafting, $7.5 \mathrm{~cm}$ in diameter and $165 \mathrm{~cm}$ long. The rotary assembly is supported with pillow block bearings, one each at both ends.

A trough that receives the husks before feeding them inside the cylinder is placed above the right side of the machine.

Two hoppers are installed in the machine, one located in front and the other positioned at the rear, which serve as separate passages of coir and dusts, respectively. A 2-hp, 3-phase electric motor that serves as the power unit, is connected to the rotary assembly by means of two 3 -groove pulleys.

The machine is capable of decorticating two (2) tons of husks per day recovering $40 \%$ coir and $60 \%$ dust.

\section{Shredding Machine}

It is a single wood planning type machine that can process wood billet having diameters ranging from $10 \mathrm{~cm}$ to $14 \mathrm{~cm}$ and $42 \mathrm{~cm}$ long. The machine is capable of producing excelsior with dimension of $0.2 \mathrm{~mm}$ to $0.6 \mathrm{~mm}$ in thickness and $5 \mathrm{~mm}$ to $6 \mathrm{~mm}$ in width. It is powered by 10 -hp 3phase electric motor and has a capacity of $0.50 \mathrm{cu}$. m. (212 bd. ft.) of wood billets per 8 hours of operation.

\section{Blending machine}

It is a machine that mixes thoroughly the saturated coir/excelsior with cement. Its capacity is 3 boards per mix in three to five minutes per operation. It is powered by $7.5 \mathrm{hp}-3$-phase electric motor.

\section{Hydraulic Cold Press}

The machine is capable of pressing maximum of 25 piles of $8 \mathrm{~mm}$ boards in one cycle of operation. Six cycles of operation can be made with a total output of 150 pieces of 8 -mm boards per day. It is powered by 15-hp, 3-phase electric motor coupled with hydraulic pump that can generate an effective pressure of 1,500 psi.

\section{Trimming Machine}

It is used to trim the boards with dimension of $61 \mathrm{~cm}$ wide by $2.44 \mathrm{~m}$ long. It has a rail measuring $51 \mathrm{~cm}$ wide and $10 \mathrm{~m}$ long and a carriage, $56 \mathrm{~cm}$ wide by $2.3 \mathrm{~m}$ long, which is fitted to the rail by means of roller bearings. Two $31 \mathrm{~cm}$ diameter circular saws with tungsten carbide teeth spaced $61 \mathrm{~cm}$ apart using one inch steel shafting and supported by two pillow block bearings at both ends are installed parallel to the rails $3.4 \mathrm{~m}$ from the starting point and $6.8 \mathrm{~m}$ from the receiving end. Another single $31 \mathrm{~cm}$ circular saw is installed across the rail $3.4 \mathrm{~m}$ away from the exit point of the 
two circular saws. The two circular saws serve as trimmer along the length of the board while the single circular saw serves as a trimmer across the board to produce a $0.61 \mathrm{~m}$ x $2.44 \mathrm{~m}$ long CWCB. A $2.5 \mathrm{hp}$ electric motor serves as the power unit of the two circular saws, while $1.5 \mathrm{hp}$ electric motor is used to power the single circular crosscut saw.

A $9.5 \mathrm{~m}$ galvanized exhaust $10-\mathrm{cm}$ diameter pipe is installed from the saws to the exit point where a blower is connected to collect the dust generated during the trimming operation. The dust is automatically deposited in an enclosed container to prevent air pollution. The blower is run by a 7.5 hp electric motor.

\section{Dipping tanks (2 units)}

Made of concrete hollow blocks, each dipping tank measures 1.0 meter high, 3.0 meters wide and 4.0 meters long with a total capacity of 12.0 cubic meters. The tanks are used separately for soaking coir and excelsior.

\section{BUILDING AND LOT REQUIREMENT}

The CWCB plant requires a building floor area, for production and storage, of 510 square meters; office and workmen's area of 90 square meters, and, lot area of 1,000 square meters. Figure 1 shows the CWCB plant layout.

\section{PLANT CAPACITY AND MANAGEMENT}

The plant is expected to produce 150 boards per day in an 8-hour operation of 37,500 boards per year with a total of 250 working days. It employs one manager, a plant supervisor and a bookkeeper/typist. Production staff is composed of 16 technicians, namely: two decorticating machine operators, two shredding machine operators, five raw material preparation technicians, two blending machine operators, two hydraulic press operators, two trimming machine operators and one lifter operator.

\section{PRODUCT DESCRIPTION}

CWCB is a composite product made from coir, shredded wood and cement. It is cheap, durable and requires low maintenance cost. The production technology is simple and the manufacturing process requires equipment and machinery that do not need highly skilled operators.

CWCB can be fabricated into modular structure to accelerate building construction. It is water-resistant and has fire retardant characteristics. It is a good insulating material, resistant against attack of wood-boring insects and decay fungi, nailable, plasterable and sawable.

\section{STATUS OF THE TECHNOLOGY}

The technology of CWCB production is in its piloting stage at the Timber Utilization Division, PCA-Zamboanga Research Center, San Ramon, Zamboanga City. It is being introduced for commercialization to G.C. Enterprises-Zamboards, a private company engaged in the manufacture of woodwool-cement boards with its plant located at Pamucutan, Zamboanga City.

\section{POTENTIAL USES AND MARKETS OF CWCB}

Commercial production of CWCB is expected to contribute to the government's national shelter program, specifically on socialized and low-cost housing. The demand for building materials is expected to increase due to the continuous increase in the number of private and government 
housing projects. Out of the annual production of 37,500 boards, about 375 units of 2-bedroom lowcost houses ( 50 square meters floor area houses) can be constructed.

CWCB can replace construction materials such as tiles, bricks, plywood, asbestos and cement hollow blocks. It is used for internal and exterior walls, partitions and ceiling. It can also be used as a component in the fabrication of furniture, cabinets, boxes and vases, among others.

Potential market outlets are construction material suppliers, building contractors and government/private agencies involved in low-cost housing projects. Other target markets are the low and middle-income households who would like to own houses at affordable prices.

\section{FINANCIAL ASPECTS}

The financial estimate of CWCB production is presented in Appendix A. It includes major assumptions and summary of findings in establishing a CWCB plant. For a ten-year period of operation, the projected production cost, net income statement, amortization schedule and cash flow are presented in Tables 1, 2, 3 and 4, respectively.

Results of the analysis show that the project is profitable, indicating a benefit-cost ratio (BCR) of 1.25 and internal rate of return (IRR) of $35.20 \%$. The investment costs can be recovered in 2.68 years of operation assuming that all the boards produced are absorbed in the market.

\section{REFERENCES}

PALOMAR, R.N. et al., 1996. Design, fabrication and evaluation of prototype coconut husk decorticating machine. The Philippine Journal of Crop Science, 11 (1):45), (Suppl.1Abstract). Also in: Philippine Journal of Coconut Studies, 21 (1):31-41

PALOMAR, R.N. J. PENAMORA, A.E. GO, E.L. ILUSTRISIMO, and D.B. RAVELO. 1996. The use of coconut coir for fiber board production. In: Proc. Regional Symposium of R \& D Highlights, August 15, 1996, CV-CIRD, Cebu City

PALOMAR, R.N. L. J. PENAMORA and A.E. GO. 1997. Utilization of coconut husk fibers and other cellulosic materials for the production of cement-bonded panels. In: Proc. Regional R \& D. Symposium, July 23, 1997. New Astoria Hotel, Zamboanga City.

PALOMAR, R.N. A. E. GO, E.L. ILUSTRISIMO and L.I. FAJARDO. 1998. Processing and utilization of coir-wood-cement board. Philippine Journal of Crop Science, 23(1):54., Suppl. 1 - Abstract.

PALOMAR, R.N. 1999. Commercialization of decorticating machine for coconut. In: Proc, Technical Session - Agri-Aqua Fair '99 in connection with the celebration of Farmers' and Fisherfolk’s Month, May 25, 1999, BSWM Conventional Hall, Diliman, Quezon City.

PALOMAR, R.N. Coir-wood-cement board: Potential alternative construction material. Technology Primer No. 5. Philippine Coconut Authority . 


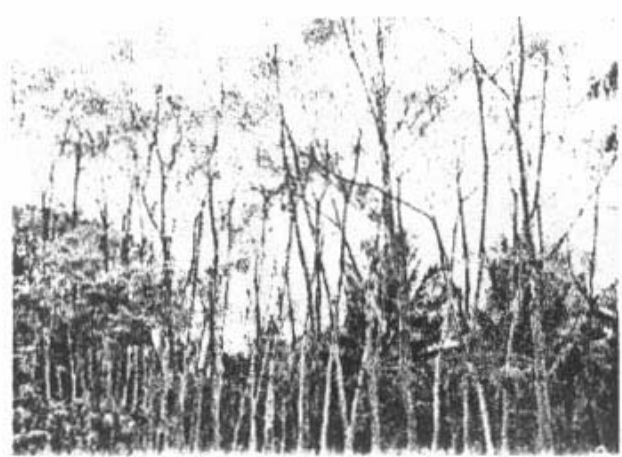

Fig. 1. Bagalunga trees grown in coconut plantation.

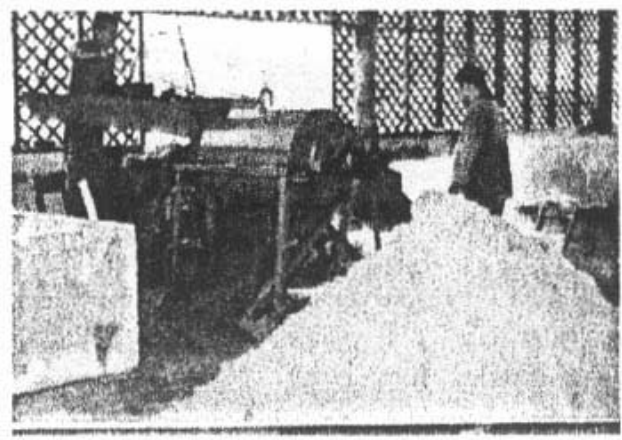

Fig. 3. Prototype decorticating machine.

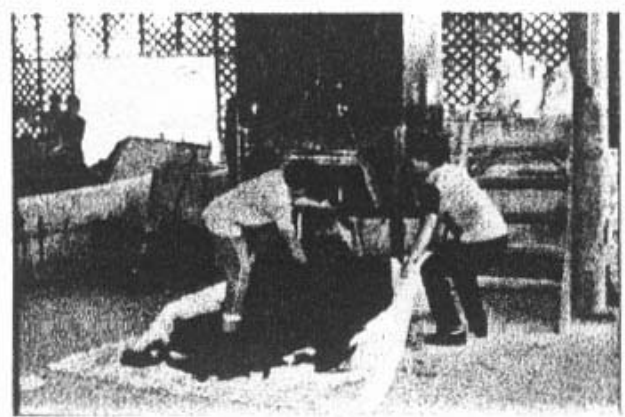

Fig. 5, Blending machine.

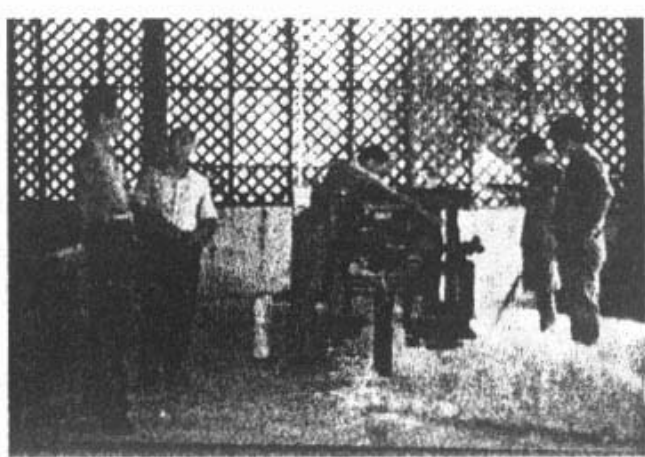

Fig. 2. Shredding machine.

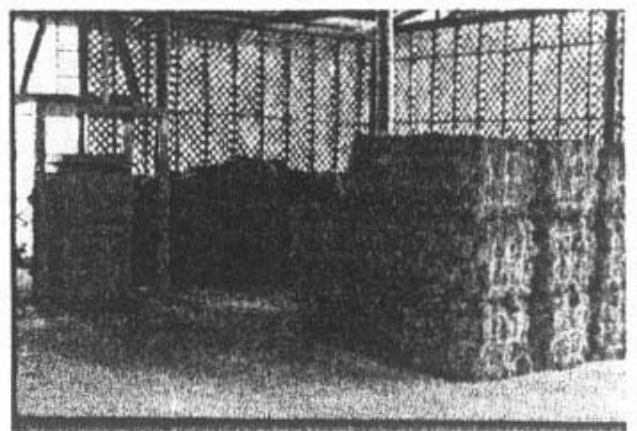

Fig. 4. Baled coir showing the baling machine.

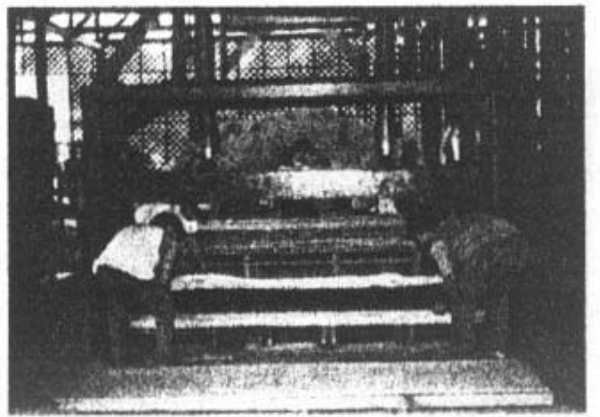

Fig. 6. Hydraulic pressing machine. 


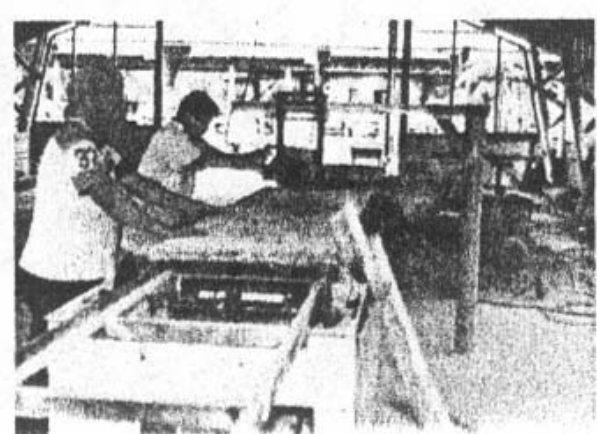

Fig. 7. Trimming machine.

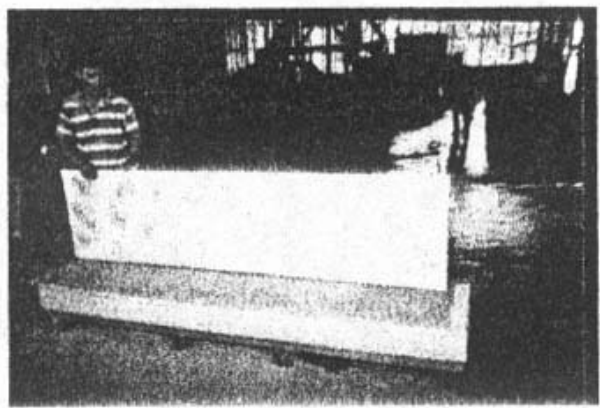

Fig. 9. CWCB with design.

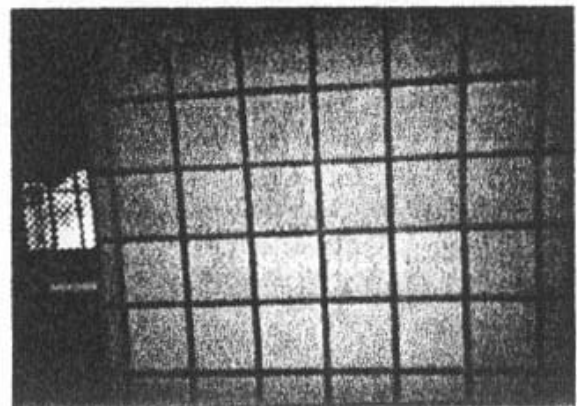

Fig. 11. CWCB as inside walling

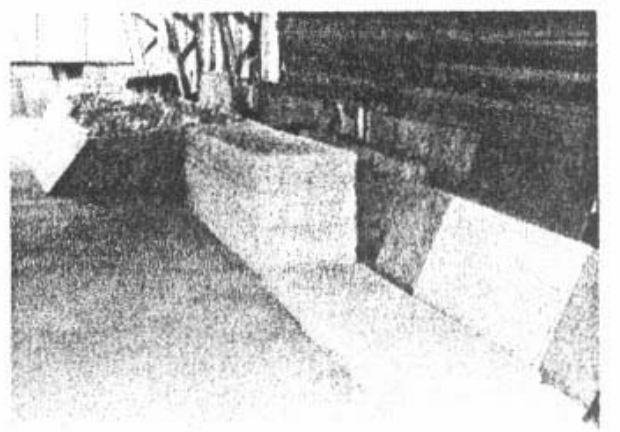

Fig. 8. Coir-wood-cement boards.

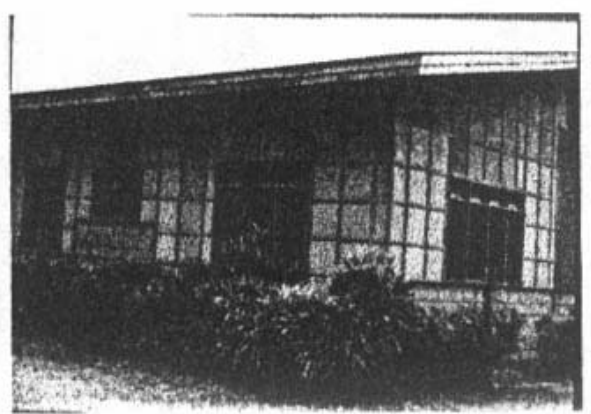

Fig. 10. Workshop building using CWCB as outside walling.

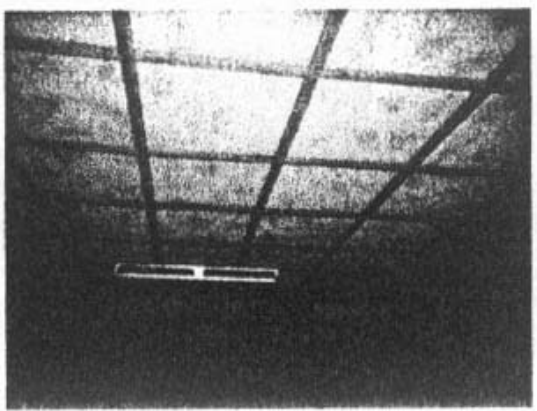

Fig. 12. CWCB as ceiling 